\title{
THE MODEL OF HUMAN RESOURCES PERFORMANCE IMPROVEMENT THROUGH EMOTIONAL INTELLIGENCE AND SPIRITUAL INTELLIGENCE BY LEARNING ORIENTATION AS INTERVENING VARIABLE
}

\author{
Nur Laily Monita Arti*
}

* Affiliation:
Universitas Islam Sultan
Agung Semarang
Email:
monitaarti0@gmail.com

monitaarti0@gmail.com

\section{Abstract :}

The purpose of this research is to analyze and examine between the variables of emotional intelligence, spiritual intelligence and learning orientation to human resources performance in an organization. This research used purposive sampling with 131 people as respondents. Data collection techniques used in this study is questionnaires and interviews. Data analyzed by using SPSS 19 software with regression test to find out the determine of independent variable to dependent variable, independent variable to intervening variable and intervening variable to independent variable. Demonstrate that human resources performance can be improved by increasing the intensity of learning orientation, emotional intelligence, and spiritual intelligence. Learning orientation has a significantly positive influence on human resources performance. While emotional intelligence and spiritual intelligence have a significantly positive influence on human resources performance. So in this research, emotional intelligence, spiritual intelligence and learning orientation have a significantly positive influence on human resources performance.

Keywords : emotional intelligence, spiritual intelligence and learning orientation, human resources performance

\section{INTRODUCTION}

In the face of competition in the era of global companies are expected to work more efficiently and effectively. The increasingly rigorous competition is causing companies are expected to increase competitiveness in order to maintain the viability of the company. The company is one of the organizations that brought together people who are commonly referred to with the human resources (HR) or employees to run the household production activities of the company. Almost all companies have a purpose and that is to maximize profit and value for thecompany, and also to improve the welfare of the owners and human resource. 
The performance is a must-have every potential human resource in order to carry out the duties and responsibilities of a given organization for HUMAN RESOURCES. The performance itself can be reached by a person or a group of people within an organization, in accordance with the authority and responsibilities of each in improving the performance of human resources. HR performance can also be seen from the aspect of the quantity of work include the quality of work and accuracy of work, skill levels in the work, the ability to analyze the data, and the ability to evaluate.

The development of human resources is an effective way to deal with some of the challenges faced by many companies. One of them is by doing a learning orientation. Organizational learning requires time to use human resources organizations to pursue knowledge beyond the scope of their work. If your organization does not encourage knowledge development, human resources will not be motivated to undertake learning activities (Calcantone, Cavusgil. and Zhao, 2002 in Widjayanti and Widodo, 2014). The learning process should be a corporate culture so that the skills of human resources can be maintained, even improved. Optimal learning orientation is expected to have the right benefits for human resources. Next in the perspective of any religion (in this case Islam), "learning is an obligation for every Muslim in order to acquire knowledge so that increased life degree movies". It is stated in surah Mujaddalah verse 11 which means "Allah will raise those who have believed among you and those who were given knowledge by degrees". The explanation of "the science in this course must be the knowledge that is relevant to the demands of the times and of benefit to the lives of many.

According to Hawari (2006) "the ability of a person of which is determined by the intelligence of its own, there are a number of intelligence on human beings, among them: the intellectual intelligence emotional intelligence, intelligence, creativity, and spiritual intelligence ". According to (Mangkunegara, 2010) "the majority of human resource in developing countries including Indonesia still has emotional intelligence. It became one of the causes of the weak quality of human resources in Indonesia. Goleman (2001, p. 39) stated that "emotional intelligence is the ability to monitor and control your own feelings and others as well as use these feelings to guide the thoughts and actions so that emotional intelligence is very necessary for success in work and produce an outstanding performance on the job".

In addition to emotional intelligence, Zohar and Marshall (2000) explain that "spiritual intelligence also play a role in a person's success in work. An employee obtains happiness in work will work better. Trihandini research results (2005) concluded that "spiritual intelligence have real influence on the performance of employees". Spiritual intelligence, in addition to affecting an employee job satisfaction also give impact on the performance of an employee. This is in line with research done Achmad Sani Eka Supriyanto and Afnan Troena (2012) proves that "spiritual intelligence a significant effect on performance". Lisda Rahmasari (2012) stated "positive effect against spiritual intelligence employees performance", and research Rica Senses Handayani, Sutrisno, Sugeng Iswono (2014), which also states that "there is the influence of spiritual intelligence against the performance of the employee ". This result means that increasing the level of spiritual intelligence, then the performance will be increased. 
Trangkil sugar factory (PG Trangkil) is one of the sugar factories in Central Java and is the largest with production sugar factory in Central Java. Therefore this research aspects influenced the phenomenon is a matter of the human resources performance expectations regarding emotional and spiritual intelligence that will have an effect on the orientation of the human resources learning PG Trangkil later make the end result how human resources can achieve the performance well. Each organization would certainly expect a good performance from its human resources. Same is the case with PG Trangkil which is still not optimal, so the impact on the performance of human resources. As shown in the following table :

\section{Table 1.1}

\section{TARGET AND PERFORMANCE OF TEBU TERGILING PG TRANGKIL YEAR 2010 S/D 2017}

\begin{tabular}{|l|l|l|l|}
\hline Year & Target (Ton) & Actual Target (Ton) & Percentage (\%) \\
\hline 2010 & 900.000 & 966.339 & $107,4 \%$ \\
\hline 2011 & 900.000 & 677.170 & $75,2 \%$ \\
\hline 2012 & 900.000 & 910.000 & $101,1 \%$ \\
\hline 2013 & 1.100 .000 & 1.053 .000 & $95,7 \%$ \\
\hline 2014 & 1.200 .000 & 965.000 & $80,4 \%$ \\
\hline 2015 & 1.200 .000 & 853.905 & $71,2 \%$ \\
\hline 2016 & 1.400 .000 & 981.431 & $70,1 \%$ \\
\hline 2017 & 1.500 .000 & 989.825 & $66 \%$ \\
\hline
\end{tabular}

Source : PG Trangkil, 2017

The whole potential of human resources hasn't been able to steer employees toward tasks and functions that cause a decrease in the actual target that happens in 2012 until 2017. The TBS can still have not felt responsive through previous learning orientation using only manual reports, now the human resources required to create a new report with a work-based system online. In addition, emotional intelligence factors also became a reference in performance measurement, this is because the employee is still lacking for the ability to coordinate the emotions in themselves, as well as doing a quiet thought without emotion.

\section{LITERATURE REVIEW}

\section{Human Resources Performance}

Performance (performance) is an indicator used to measure the level of achievement of the implementation of a programme of activities that are reflected through the achievement of the goals, vision and mission and goals of the organization. (Moeheriono, 2009) stated that the performance is the result of work that can be accomplished by individuals or a group of people within an organization either quantitatively or qualitatively, in accordance with the authority and responsibilities of each, in an effort achieve the objectives of the organization legally and does not violate the law. How organizations respect and treat the human resources (HR) will affect their behavior in running performance (Wibowo, 2010). The performance management process includes how to manage people and items elements in it to create a shared 
understanding between superiors and subordinates on what must be achieved (the final result to be achieved) and how to achieve them (competencies required), so that will increase the ability of the achievement of business goals that are applied.

Thus some of the sense of the above can be inferred that the performance is a result of the achievements or results of the work can be measured both qualitatively as well as quantitatively, as well as illustrate the extent to which an organization has managed to reach the goal has been established. In addition, the performance also shows how well the behavior of the human resources in an effort to create a destination company.

\section{Learning Orientation}

According to Watkins and Marsick (2003) in Uniati (2014), organizational learning can be defined as an integrative system applied in the workplace and the environment to support the learning process. Learning Organization (LO) illustrates that learning (learning) was a prerequisite over the success of the occurrence of a change and organizational performance (Che Rose et al. 2009). According to Decenzo \& Robbins in Sedarmayanti (2010:114) that "orientation is an activity that involves the introduction of new employees to the Organization and their work units." According to Wether \& Sedarmayanti in Davis (2010:114) that "orientation is familiarizing employees with the role, organization, organizational policies, and other employees". "Orientation is a procedure of granting the information about the principal company to new employees". (Dessler dalam Marwansyah, 2010:141).

According to Stata in Bagas Prakoso $(2005$; 43) posited that "learning orientation is a process where individuals will gain knowledge as well as new insights that would modify their behavior and their actions." Meanwhile, according to Gregory in Joubert B Maramis (2008; 29) that "learning orientation is a culture where employees agree upon basic values will be how important learning."

From the above, it can be concluded that learning Orientation is the provision of basic information relating to the company for HUMAN RESOURCES new information they need in order to carry out its work satisfactorily. Basic information the new insights that include facts such as hours of work, how to obtain identification cards, payment of wages and the ones who are going to work with her. The orientation is primarily one of the components of the new employee socialization process, i.e. a process of cultivation of the attitude, standards, values, and behavior patterns that apply within the company to the new human resources.

\section{Emotional Intelligence}

According to Robbins (2003, p144) "emotional intelligence refers to one diversity of skills, capabilities, and cognitive competence, affecting a person's ability to succeed in the face of the demands and pressures of the environment". While the "emotional intelligence or Emotional Intelligence refers to the ability to recognize our own feelings and the feelings of others, the ability to motivate yourself, and the ability to manage emotions in themselves and in their relations with the others (Goleman 2005,p512)".

According to Salovey and Mayer as delivered by Goleman (2005, p513), "defining emotional intelligence as a traffic monitor and control your own feelings and others, as well as 
using the feelings it to guide the thoughts and the action ". While according to Weisinger (2006) simply put, the "emotional intelligence is the use of emotion intelligently. These emotions are useful as Guide Your thinking and behavior so that your results increase. Weisinger holds emotional intelligence as an instrument to resolve a problem with a co-worker, make a deal with a customer who is cranky, criticize your employer, complete the task until it is finished, and in different challenges others that affect the success of human resources".

From some of the opinions above it can be concluded that emotional intelligence is a person's ability to understand the emotions of oneself and other people's emotions, motivating oneself, as well as establishing relationships with others. And emotional intelligence can be used to guide human thought and behavior to avoid unwanted things happen.

\section{Spiritual Intelligence}

Spiritual intelligence (SQ) is the intelligence to confront and solve the question of the meaning of life, values, and integrity of yourself i.e. intelligence to get the behavior and our lives in the context of a broader meaning and rich, intelligence to the rate that the action or the way someone's life more meaningful compared to the others. One can find the meaning of life from work, learn and ask questions while facing problems or suffering. Spiritual intelligence is the intelligence of the soul that helps heal and build yourself a human being as a whole. According to Tony Buzan, a "spiritual intelligence is related to being part of the design of everything bigger, includes" see a thoroughly".(Tony Buzan, 2003, hal. 80).

(Kartini Kartono, \& Dali Gulo, 2000, p. 233) The title of the Spiritual Sense, the characteristics and the definition of SQ according to experts "spiritual is the basis for the growth of self-esteem, values, morals, and sense of belonging. He gives direction and meaning for our lives about belief about the existence of a nonphysical strength greater than on the strength of ourselves, an awareness that connects us directly with God, or whatever we call as a source our existence ". Spiritual intelligence is the foundation needed to enable the IQ and EQ effectively. In fact, it is the highest intelligence of the SQ (Zohar \& Marshall 2001, p. 12-13) States "that spiritual intelligence allows one to recognize the value of traits in others and in themselves".

Zohar and Marshall defines spiritual intelligence as "intelligence to confront and solve the question of meaning and value, i.e. intelligence to put life and behavior in the context of a broader meaning and rich, intelligence to the rate that the action or the way someone's life more meaningful than anything else ". (Mizan, 2001, p. 4) "Spiritual intelligence are well developed will be marked with the environment, have a high level of awareness, being able to face the suffering and pain, was able to take the lessons from the failure, capable of manifesting life in accordance with its mission and vision, able to see the link between things, independently, and in the end make someone understand the meaning of his life".

From some of the above, it can be concluded that the sense of spiritual intelligence is the ability of the human beings can realize and determine the meaning, values, morals, and a greater love towards our fellow beings because human beings are aware of and feel that humans include a part of the whole life. So that man can put themselves, can live better, more positive and can recognize the value of those qualities in others. 


\section{RESEACRH METHODS}

This research was conducted to obtain a description of the model of human resources performance improvement through emotional intelligence, spiritual intelligence by learning orientation as an intervening variable. With respect to such matters, then in the implementation of this research will be used in the type or form of verification research conducted through the collection of data in the field, namely PT Kebon Supreme sugar mill Trangkil Pati and research methods the survey method is used. " The form of a quantitative research method research based on the philosophy of positivism is used for research on population and sample, and analysis of data are statistics with the aim to test the hypothesis that has been established ( Sugiyono, 2015:14). "Data collection Method survey that is conducted against the real object by taking a sample from a population by using a questionnaire as a data collection tool staple (Sugiyono: 2015:15).

The data used in this research is quantitative data. This research aims to find out which is the most dominant Factor in affecting the performance of human resources at PT Kebon Agung sugar mill trangkil Pati through learning orientation, then the methods of analysis used in the study using multiple linear regression analysis and Path Analysis. Multiple linear regression analysis basically aims to know is there any influence between the two variables, if there is a significant influence on both of them. Free and bound variables are then arranged in the shape of the instrument now. The now first tested validity and reliability prior to use in the field.

\section{RESULT AND DISCUSSION}

\section{Influence of emotional intelligence Against Learning Orientation}

Influence of emotional intelligence test results against a learning orientation obtained results that the value $t$ calculate the significance and value of 2.241 of $0.027<0.05$. The significance level of $5 \%$ on the value of the degrees of freedom $(\mathrm{dk}=131-2-1=128)$ then retrieved t tebel of 1.979 smaller than $t$ count i.e. of 2.241. It showed that emotional intelligence is a positive and significant effect against the learning orientation so that the hypothesis stating the emotional intelligence of influential positive orientation towards and significant learning proven or accepted.

\section{The Influence Of Spiritual Intelligence Against Learning Orientation}

Results of testing the influence of spiritual intelligence against the orientation study obtained results that the value $t$ calculate of 2.323 and value the significance of $0.022<0.05$. The significance level of $5 \%$ on the value of the degrees of freedom $(\mathrm{dk}=131-2-1=128)$ then retrieved the $t$ table of 1.979 smaller than $t$ count i.e. of 2.323. It showed that the influential spiritual intelligence positively and significantly to learning orientation so that the hypothesis stating the influential spiritual intelligence positively and significantly to learning orientation proved or accepted.

\section{Influence of emotional intelligence on the performance of human resources}

Influence of emotional intelligence test results against the performance of human resources obtained results that the value t calculate of 2.249 and value the significance of 0.026 
$<0.05$. The significance level of $5 \%$ on the value of the degrees of freedom $(\mathrm{dk}=131-2-1=$ 128) then retrieved t tebel of 1.979 smaller than $t$ count i.e. of 2.249. It showed that emotional intelligence is a positive and significant effect on the performance of human resources so that the hypothesis stating the emotional intelligence of influential positive and significant human resources performance against proven or accepted.

\section{The Influence Of Spiritual Intelligence On Performance Of human resources}

Results of testing the influence of spiritual intelligence on performance results obtained that the HR value t calculate the significance and value of 2.662 of $0.009<0.05$. The significance level of $5 \%$ on the value of the degrees of freedom $(\mathrm{dk}=131-2-1=128)$ then retrieved tebel of 1.979 smaller than $t$ count i.e. amounting to 2.662. It showed that spiritual intelligence positive and significant effect on the performance of human resources so that the hypothesis stating the influential spiritual intelligence positively and significantly to the human resources performance proven or accepted.

\section{The Influence Of The Orientation Of The Study On Performance Of Human Resources}

The test results influence the orientation of the study on the performance of human resources obtained results that the value $t$ calculate of 4,812 and value the significance of 0.000 $<0.05$. The significance level of $5 \%$ on the value of the degrees of freedom $(\mathrm{dk}=131-2-1=$ 128) then retrieved $t$ tebel of 1.979 smaller than $t$ count i.e. of 4,812. It indicates that the positive effect of learning orientation and significantly to the performance of human resources so that the hypothesis stating orientation learning positive and significant effect on the performance of human resources proved or accepted.

\section{Influence of emotional intelligence on performance through Human Resources orientation study}

The orientation of the study would be intervening variables between the emotional intelligence on the performance of human resources can be searched for using Coefisien Unstandardized and standard error of each variable is described as follows:

\section{Figure 4.4}

MEDIATION OF EMOTIONAL INTELLIGENCE ON PERFORMANCE THROUGH HR ORIENTATION STUDY

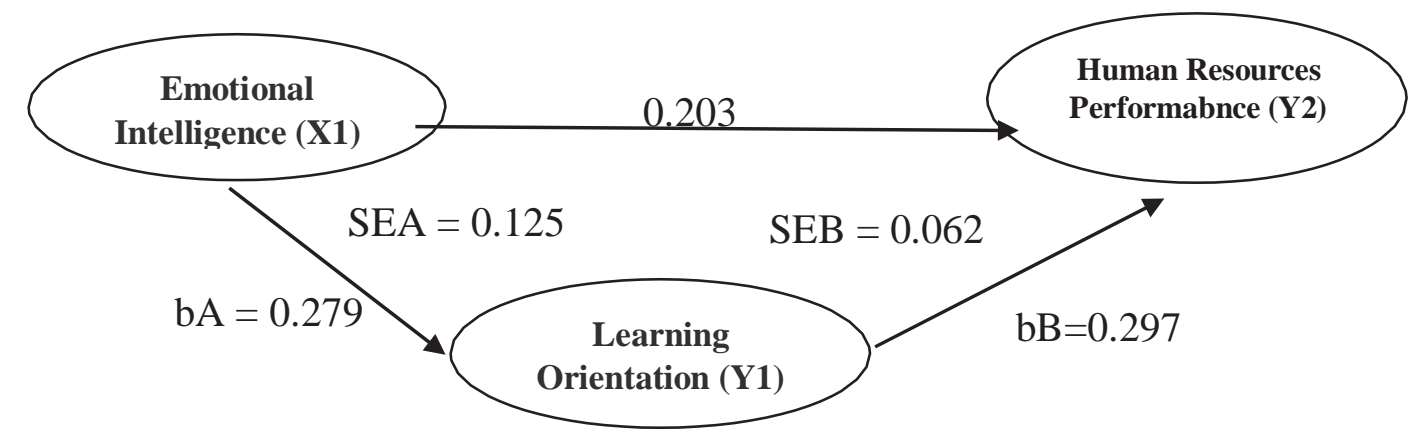


Sobel test test results to find out the influence of emotional intelligence on performance through HR orientation study obtained the value of the 2.023164 Value of sobel test $\mathrm{Z}$ count $=2.023164>1.968$. This means that emotional intelligence can mediate the influence of variables on performance HR emotional intelligence. The value of direct influence HR performance against the emotional intelligence of 0.200 . When compared with count the value of $Z$ value $Z$ count greater than 0.200 so the influence of emotional intelligence on performance SDMcenderung through a learning orientation.

\section{The influence of Spiritual intelligence on performance through Human Resources orientation study}

The orientation of the study would be intervening variables between spiritual intelligence on the performance of human resources can be searched for using Coefisien Unstandardized and standard error of each variable is described as follows :

\section{Figure 4.5}

\section{SPIRITUAL INTELLIGENCE MEDIATION TOWARDS HUMAN RESOURCES PERFORMANCE THROUGH LEARNING ORIENTATION}

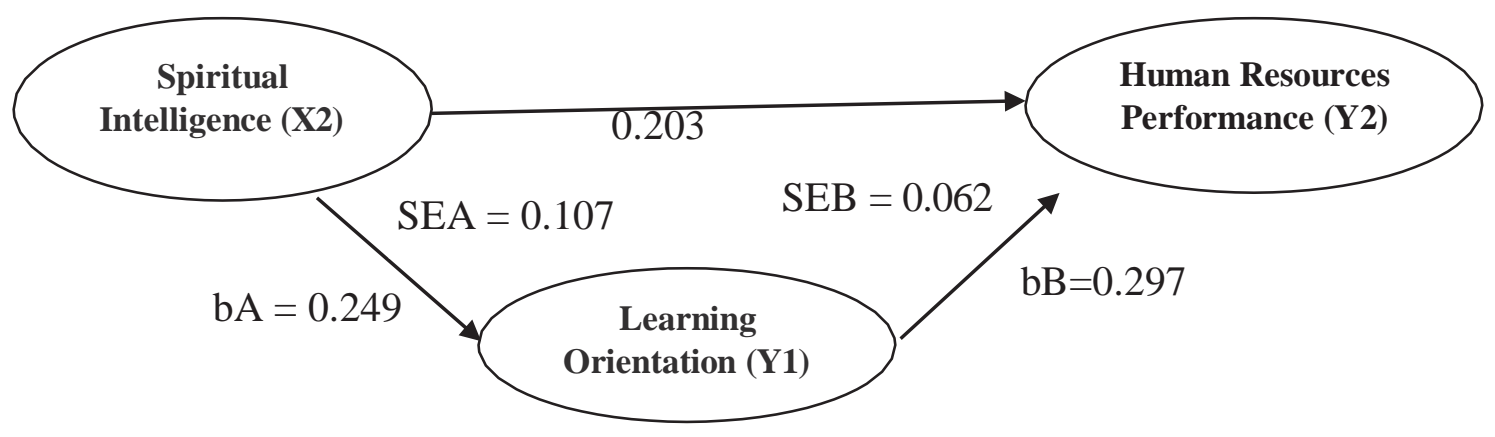

Sobel test results to find out the influence of spiritual intelligence on performance through HR orientation study obtained the value of the 2.093184 Value of Sobel test $\mathrm{Z}$ count $=$ $2.093184>1.968$. This means that emotional intelligence can mediate the influence of spiritual intelligence on performance variables of human resources. The value of direct influence human resources performance against spiritual intelligence of 0.203 . When compared to the value of $Z$ to calculate the value of count is greater than Z 0.203 , so the influence of spiritual intelligence on performance through learning orientation tends to human resources.

\section{CONCLUSION}

Emotional intelligence influential positive orientation towards learning so the more good emotional intelligence then the orientation of the study will be the better contrast in emotional intelligence is so bad then the orientation study will decrease. Spiritual intelligence influential positive orientation towards learning so the better the spiritual intelligence so the orientation of the study will be the better contrast in emotional intelligence is so bad then the orientation study will decrease. Emotional intelligence a positive effect on the performance of human resources so that the better emotional intelligence then the performance of human 
resources will be increasingly well on the contrary if emotional intelligence is bad then human resources will decrease performance.

Spiritual intelligence positive effect on the performance of human resources so that the better the spiritual intelligence then the performance of human resources will be increasingly well on the contrary if emotional intelligence is bad then the HR performance will decrease. Study of the positive effect of orientation on the performance of human resources so that the better the learning with human resources orientation it will have an impact on HR performance the better. Influence of emotional intelligence on performance tended to pass human resources learning orientation, so the more good emotional intelligence by learning orientation is good then it will have an impact on the performance of human resources which is good anyway. The influence of spiritual intelligence on performance tended to pass human resources learning orientation, so the better the spiritual intelligence by learning orientation is good then it will have an impact on the performance of human resources which is good anyway.

\section{REFERENCES}

Achmad Sani Supriyanto dan Eka Afnan Troena .(2012). Pengaruh Kecerdasan Emosional dan Kecerdasan Spiritual Terhadap Kepemimpinan Transformasional, Kepuasan Kerja dan Kinerja Manajer (Studi di Bank Syari'ah Kota Malang). Jurnal Aplikasi Manajemen, Vol.10, No.4, ISSN 1693-5241.

Al-Qur'an, Al-Qur'an dan Terjemahan.(1978). Yayasan Penyelenggara Penterjemah / Penafsiran Al-Qur'an, Departemen Agama RI., Jakarta.

Bagas Prakoso. (2005). Pengaruh Orientasi Pasar, Inovasi, dan Orientasi Pembelajaran mempengaruhi Kinerja Untuk Mencapai Keunggulan Bersaing. Jurnal Studi Manajemen \& Organisasi Vol.2 No.1 www.eprints.undip.ac.id/15063

Buzan, Tony. (2003) .Head First. Jakarta: Gramedia Pustaka Utama

Calcantone R.J, Cavusgil S.T. and Zhao Y. (2002), Learning orientation, firm innovation capability, and firm performance, Industrial Marketing Management 31, 515-524.

Che Rose, R., Kumar, N. and Ong, G.P. (2009). The Effect of Organizational Learning on Organi-zational Commitment, Job Satisfaction and Working Performance. The Journal of Applied Business Research, 25(6).

Dessler, Gary, (2010). Manajemen Sumber Daya Manusia. Jakarta: PT. Indeks.

Goleman, Daniel. (2004). Kecerdasan Emosional: Mengapa EI Lebih Penting Daripada IQ, Terjemahan oleh T. Hermaya. 2004. PT. Gramedia Pustaka Utama, Jakarta.

Goleman, Daniel. (2004). Kecerdasan Emosional: Mengapa EI Lebih Penting Daripada IQ, Terjemahan oleh T. Hermaya. 2004. PT. Gramedia Pustaka Utama, Jakarta.

Hawari D. 2006. Manajemen Stress, Cemas, Depresi. Jakarta: FKUI

Kartono, Kartini \& Gulo, Dali. (2000). Kamus Psikologi. Bandung: CV. Pionir Jay 
Lisda, R. (2012). Pengaruh Kecerdasan Intelektual, Kecerdasan Emosional Dan Kecerdasan Spiritual Terhadap Kinerja Karyawan. FE. Universitas AKI.

Mangkunegara, A. A Anwar Prabu.(2010). Evaluasi kinerja SDM. Bandung, Refika Aditama. Marwansyah. (2010). Manajemen Sumber Daya Manusia. Edisi Kedua. Bandung : Alfabeta.

Rika Indra Handayani, Sutrisno, Sugeng Iswono . (2014). Pengaruh Kecerdasan Emosional dan Kecerdasan Spiritual Terhadap Kinerja Karyawan Pada Hotel Ijen View. Artikel Ilmiah Hasil Penelitian Mahasiswa, Ilmu Administrasi Bisnis, Fakultas Ilmu Sosial dan Ilmu Politik. Universitas Jember (UNEJ).

Robbins, Stephen P. (2003). Perilaku Organisasi. Index. Jakarta.

Salovey, P. \& Mayer, J.D. (1990). Emotional Intelligence. Journal of University of New Hampshire. Baywood Publishing Co., Inc.

Sedarmayanti. (2010). Manajemen Sumber Daya Manusia Reformasi Birokrasi dan Manjemen Pegawai Negeri Sipil. Bandung: PT. Refika Aditama.marwa.

Sugiyono. (2015). Metode Penelitian pendidikan Pendekatan Kuantitatif Kualitatif dan R\&D. Bandung:Alfabeta

Trihandini, R.A. Fabiola Meirnayati. (2005). Analisis Pengaruh Kecerdasan Intelektual, Kecerdasan Emosi dan Kecerdasan Spiritual terhadap Kinerja Karyawan. Skripsi Fakultas Ekonomi Universitas Diponegoro Semarang. Semarang.

Watkins, K.E. and Marsick, V.J. (1997). Dimensions of the learning organization. Warwick, RI: Partnersfor the Learning Organization.

Wibowo. (2010). Manajemen Kinerja. Jakarta: Rajawali Press.

Zohar, D, Marshal, I. (2000). SQ (Spiritual Intelligence) : The Ultimate Intelligence, Blomsburry Publishing, London. 